\title{
AUGMENTING URBAN PARKS IN BAHRAIN FOR THE IMPROVEMENT OF CITIZENS' HEALTH
}

\author{
Imad M. Assali ${ }^{1}$ \\ ${ }^{1}$ Assistant Professor / Chairperson of Interior Design Department, College of Arts, Science \& Education, Ahlia \\ University, Kingdom of Bahrain, email: iassali@ahlia.edu.bh
}

\begin{abstract}
Research over the past three decades has provided strong evidence of the positive impact of nature on the health of human beings. Contact with nature, whether that be with plants, animals, aesthetically pleasing landscapes or with the wilderness at large in all its forms, offers a range of medical benefits. Carlson er, al. [1] those benefits may include: lower blood pressure and cholesterol levels, enhanced survival after heart attacks, more rapid recovery from surgery, fewer minor medical complaints, and lower selfreported stress. Although the Kingdom of Bahrain is a very small country, there are quite a few public parks in it: for example, Al Fateh Corniche, Arad Bay/Dohat Arad, Andalus Park, etc. In addition, strewn around residential areas, one finds many small neighborhood parks. This research suggests that the benefits of urban parks can be tapped into if the following criteria are fulfilled: First, policy makers and planners create the necessary awareness among citizens and residents of the positive impact on human health of contact with nature; second, recreational and cultural activities are conducted within those parks and green spaces; this will increase the interest of the population in frequenting them. Last but not least, parks in Bahrain need to be augmented to fit the needs of the specific country climatically as well as socially and culturally. Direct benefits can be reaped on the health of children and adults from walking and playing in parts, and indirect benefits can accrue on the health system from prevention of diseases through exercising, fresh air, and the sharing of recreational and cultural activities in those green spaces.
\end{abstract}

Key Words: Urban parks; general health benefits; recreation; societal and cultural needs; diverse activities. $* * *$
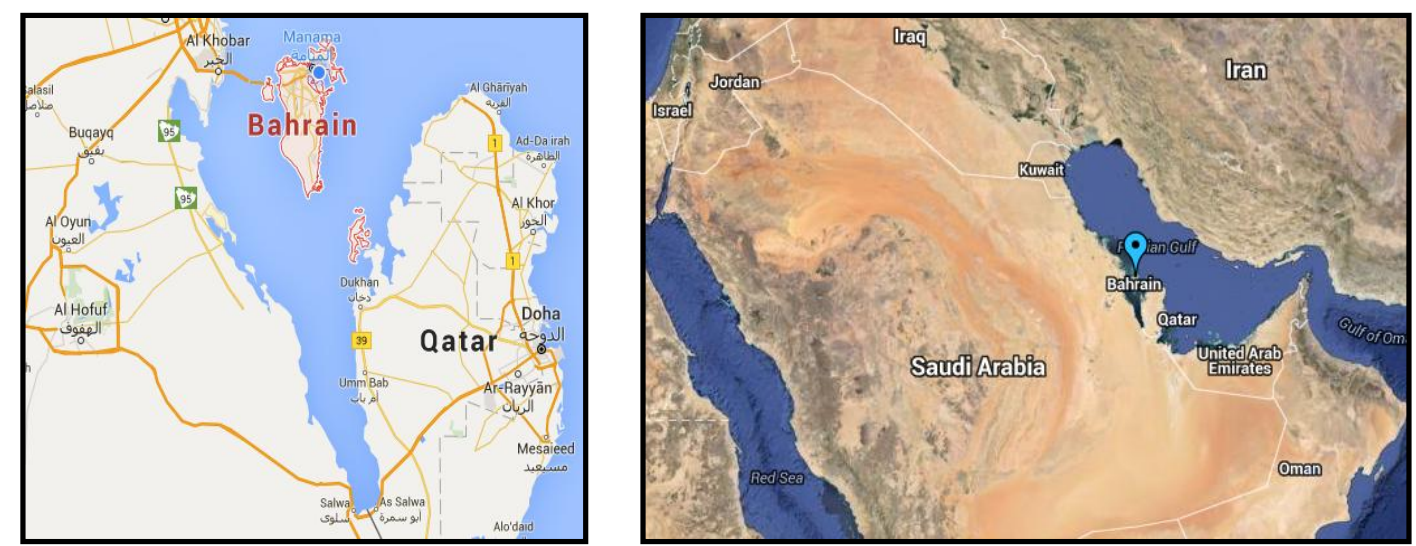

Bahrain Location in the Arab Gulf (Source: http://www.maplandia.com/bahrain/bahrain/manama)

1- Arad Bay/Dohat Arad
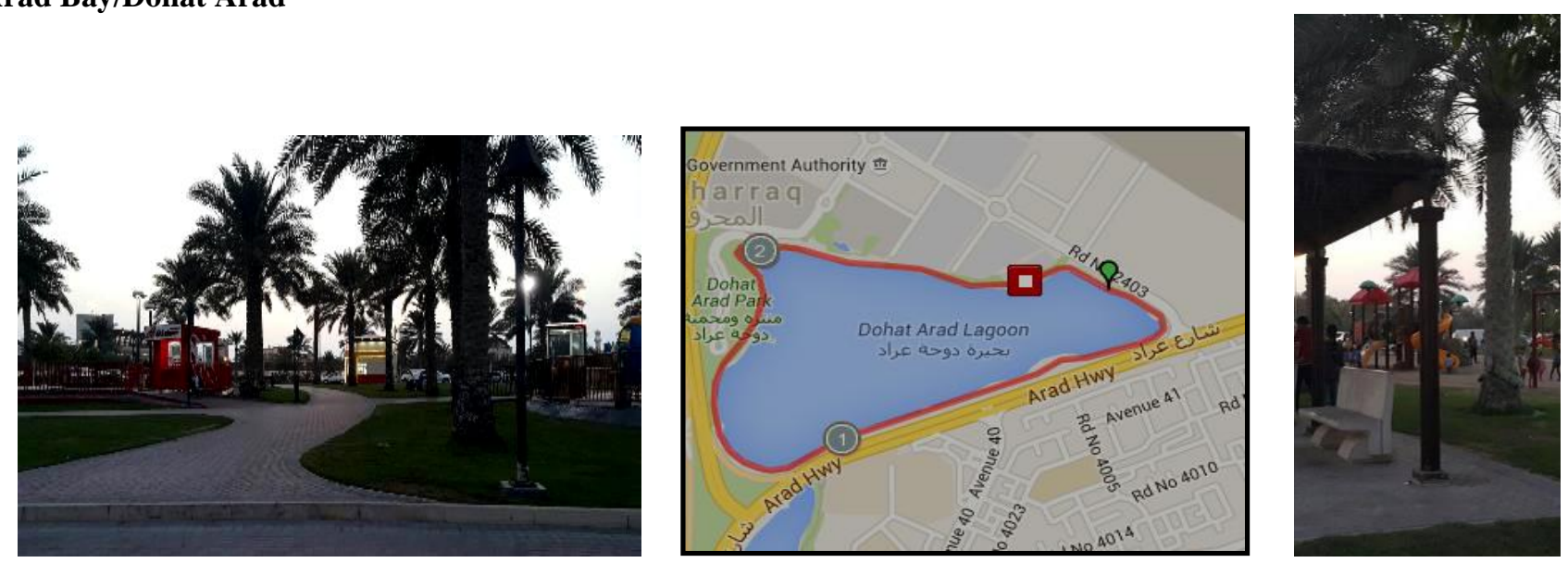

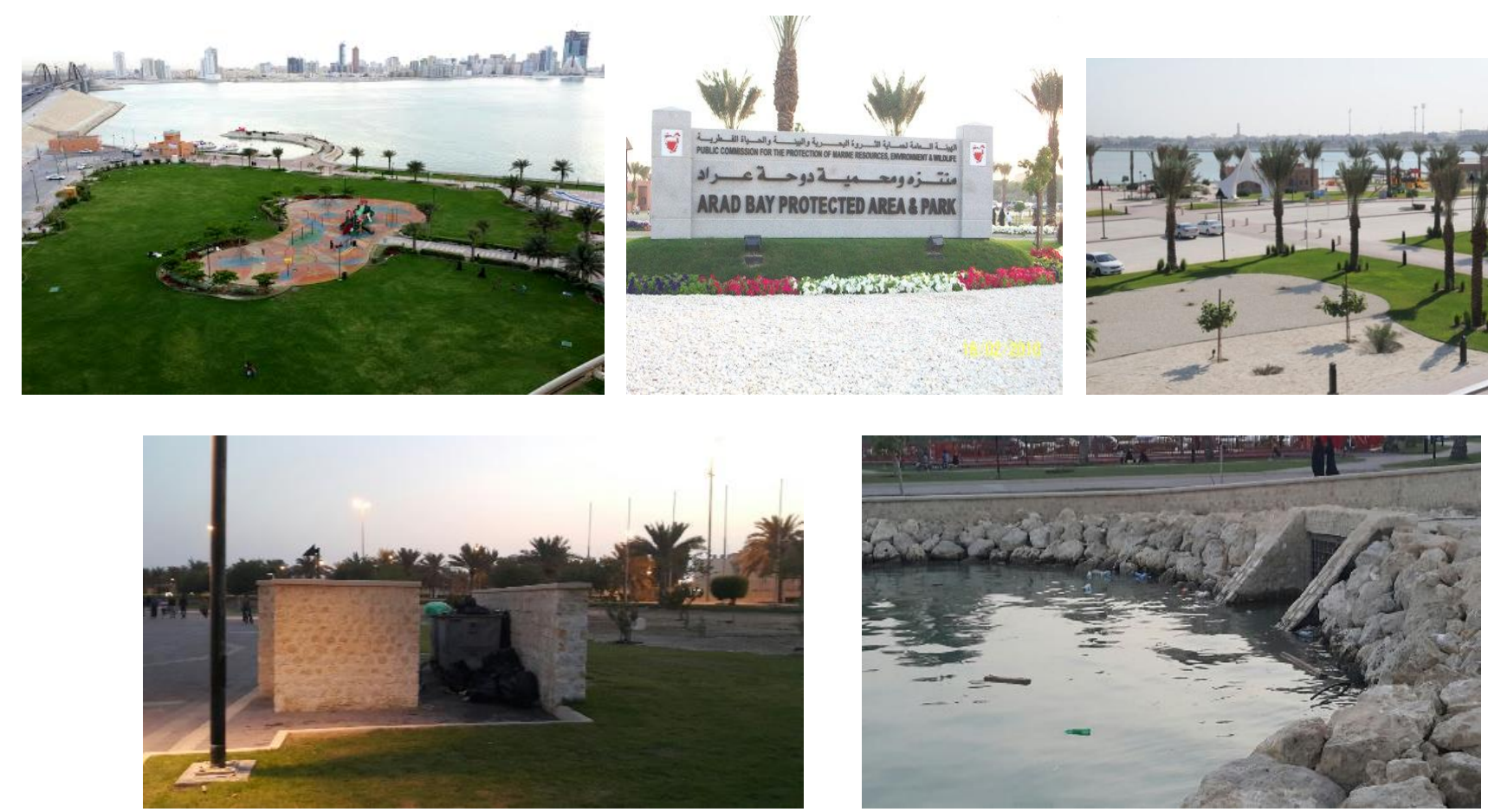

\section{2- Al Andalus Park}
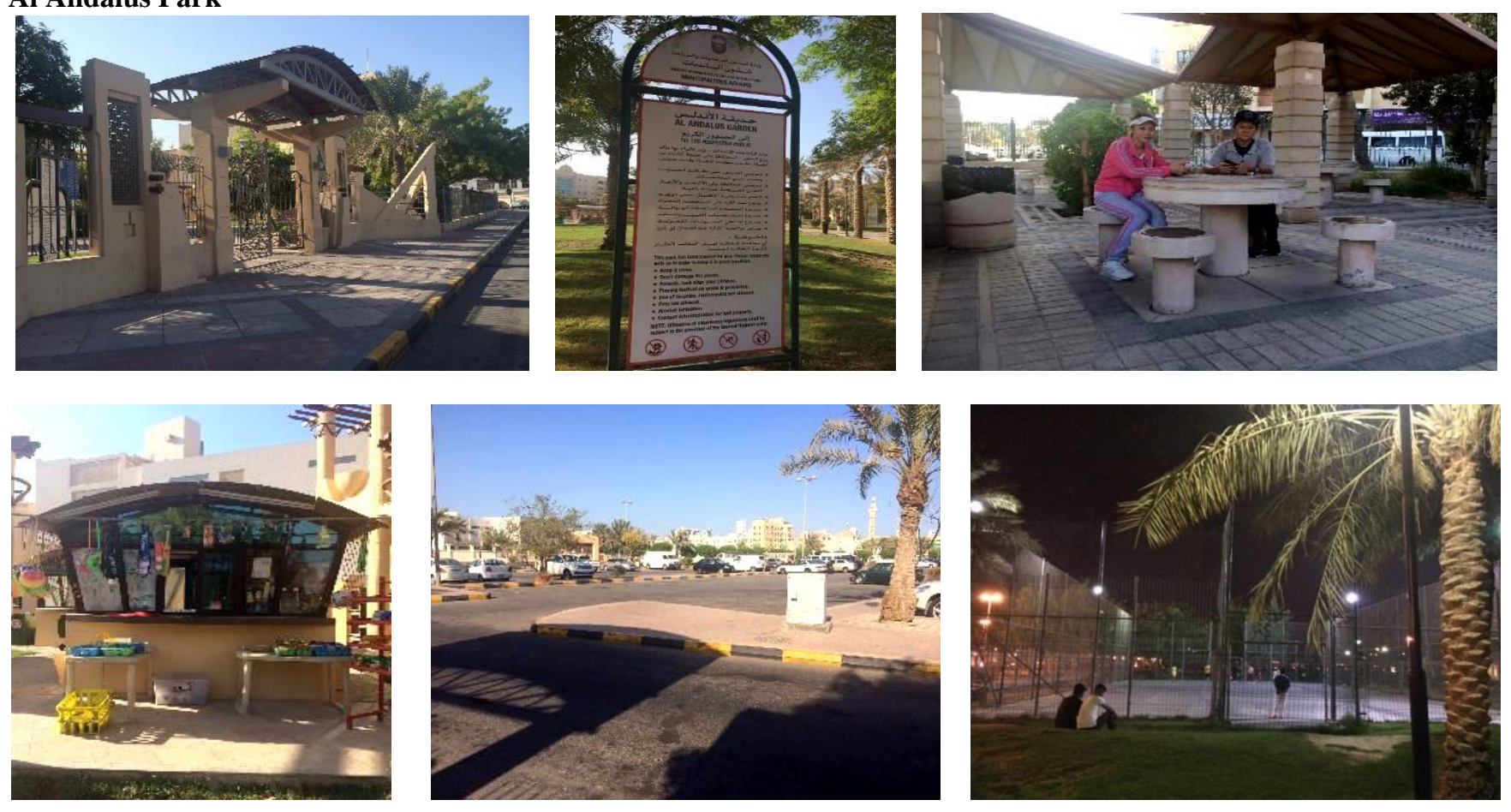

\section{3- Al Fateh Corniche}
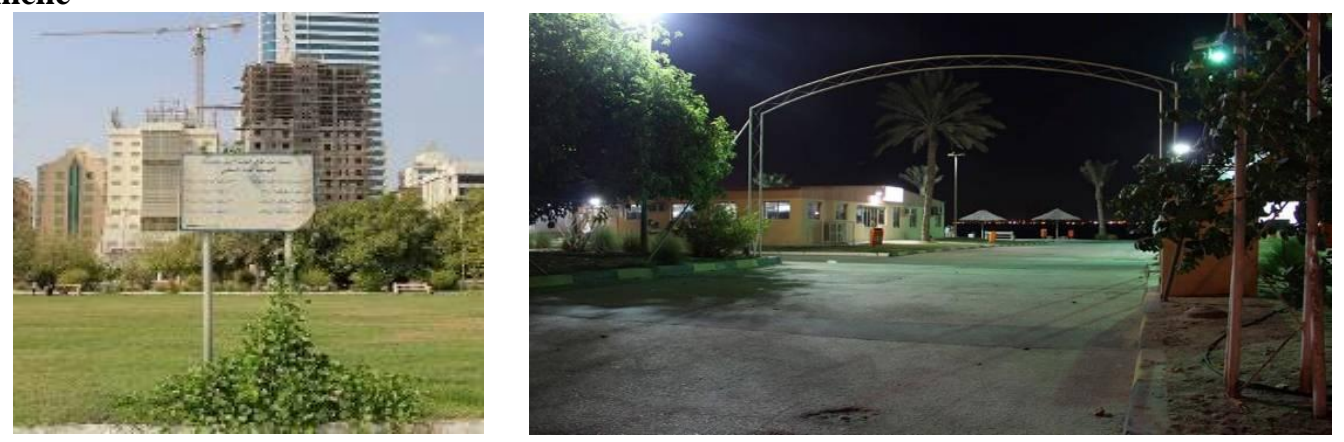

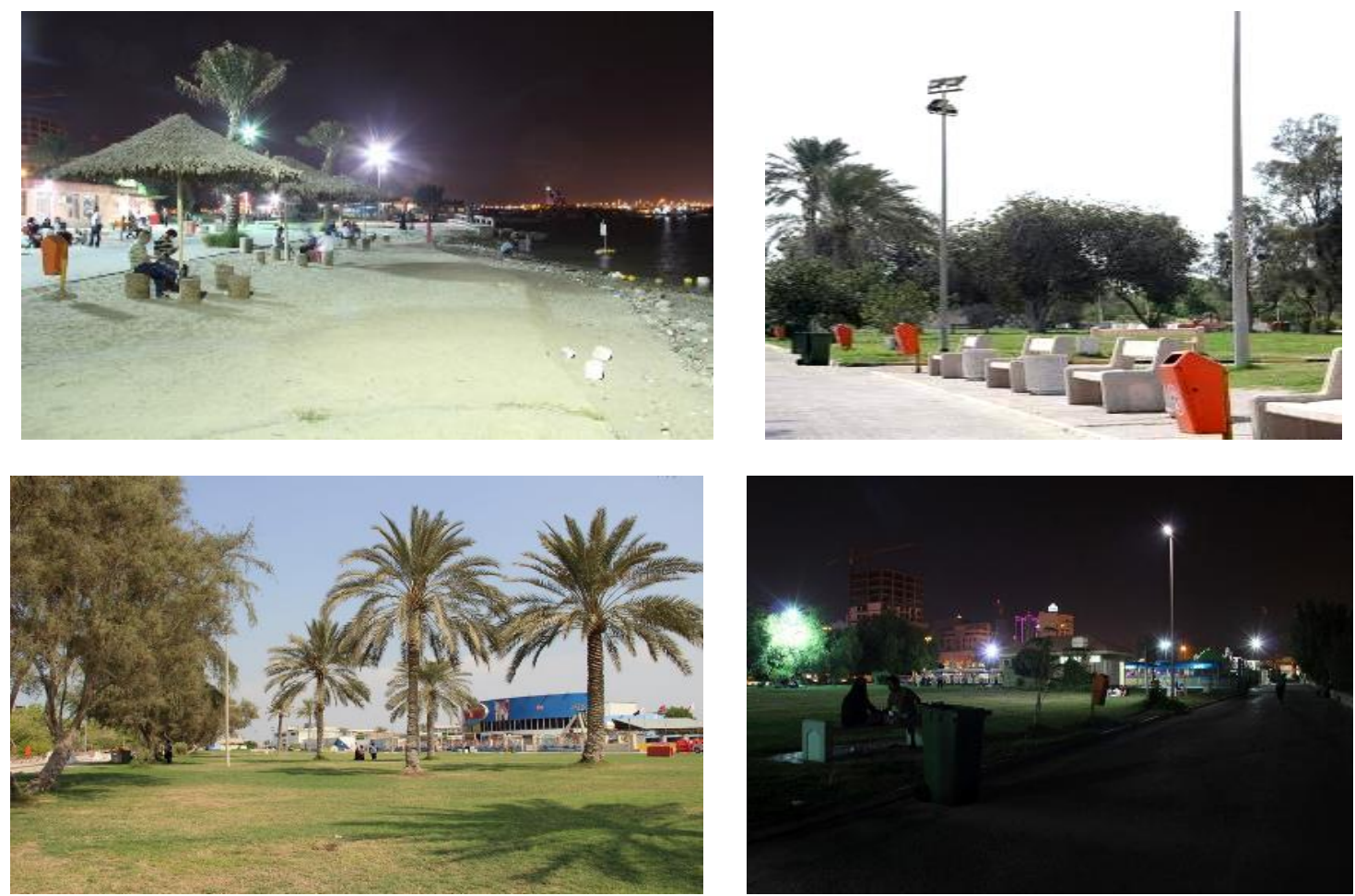

Figure 1: The research area includes the following parks in Bahrain: Arad Bay/Dohat Arad, Al Andalus Park \& Al Fateh Corniche ( Source: the author)

\section{INTRODUCTION}

"Thousands of people cooped up in rooms and corridors need a place where they can change their depth of focus and be in nature while in the heart (Quote from the landscape architect who led the design of Bryant Park's restoration $)^{2}$

According Fratini et, al. [2] urban green-spaces are normally defined as those areas that are naturally or artificially endowed with vegetation and located in the center of a city or on the periphery. Diverse studied such as Akbar et al. [3] and Chiesura [4] agree that a park experience may reduce stress, rejuvenate the city dweller, enhance contemplativeness and provide a sense of peacefulness and tranquility. Atiqul Haq [5] has shown that people who used local parks frequently were more likely to report good health than those who did not. Hanie, et al. [6] stated that natural environments with vegetation and water induce relaxed and less stressful states in observers compared with urban scenes with no vegetation. Sullivan et al., [7] considered the presence of trees and grass in outdoor common spaces may promote the development of social ties. Bahrain has been ranked among the world's top 10 fattest nations, the obesity rate is $34.1 \%$ in comparison with the world ${ }^{3}$. The study carried by Musaiger, et al. [8] about obesity found that it is a result of lack of practicing exercises, ownership of cars, availability of housemaids, family history of obesity and meal patterns and health factors. As obesity is a risk factor for some chronic diseases, the need to prevent and control it has become an essential measure to prevent chronic noncommunicable diseases in the country. Nowadays, health costs have become the biggest single expenditure in all countries; the importance of physical activity in preventing a wide variety of health problems, as well as in enhancing health in general, is now well understood. Such activities include walking, hiking, jogging, running, bicycling, as well as individual and team sports. Public parks and recreation have become a vital part of urban planning in Bahrain as awareness about their benefits increased. However, the benefits of these existing parts could be increased if certain problems were addressed.

\subsection{Research Problem}

The researcher visited different urban parks in Bahrain during different hours of the day, during weekdays and on weekends and during different seasons - and he came up with the following observations: For the purposes of exercising and walking citizens and residents tend to visit urban parks either in the very early mornings or towards late afternoon and after the sun sets down. Urban parks are almost empty during the noon hours especially during spring and summer ${ }^{4}$. Moreover, it was observed that the parks lacked a fit between their climactic conditions and the kind of vegetation planted in them and they did not contain enough shaded spaces, benches, seats, or facilities - all factors which would encourage visitors to frequent them.

2 http://www.asla.org/2010awards/403.html

3 The World Factbook:https://www.cia.gov/library/publications/the-worldfactbook/fields/2228.html

${ }^{4}$ During those seasons the temperatures reach more than 48 degrees centigrade during noon hours. 


\subsection{Research Hypothesis}

In order to affirm the research goals, the main hypothesis of the research is: " Public parks play a very important role in improving a wide variety of health problems, and applying landscape design will encourage all kinds of people to attend them and practicing physical exercise in the best way".

\subsection{Materials and methods}

The descriptive analysis method has been used in this research. First, a literature review was conducted; then the definition and classification of the green areas, standards used in their design, and the importance of their design was explored. Primary data was collected through a survey conducted among randomly selected visitors within different parks in Bahrain. The participants were informed about survey's objectives and answering procedure. Questionnaires were distributed on both weekdays and weekends, during different hours of the day, and in different areas of the parks. The questionnaire addressed a broad range of issues, ranging from frequency of visits, the fit between what the parks are offering and what the residents need, safety, accessibility, comments on available facilities and vegetation, and suggestions for improvement.

\section{LITERATURE REVIEW}

\subsection{Historical Background}

Historically, green open spaces - parks- emerged out of green lands which were used as grazing lands around cities and were later developed for recreation and social gathering. According to Nassar [9, p:16] an urban park is "any public area of land set aside for aesthetic, educational, recreational or cultural use by the public". Eventually, the uses of urban parks expanded as people became more concerned about health and fitness and hence the uses of parks increased. New demands by users impact park planning and design. In the 19th century city parks popped up all over European and North American cities as a result of rapid industrialization and mass migration to urban areas which produced crowded urban spaces and degraded the quality of urban life. Planners and landscape designers noticed that these parks constituted both a physical and mental relief from the unhealthy environment that industrialization brought upon people. Nassar [9] stated that since the 19th century, urban parks not only enhanced and beautified the urban environment, but also have become important structural components in the shaping of urban form.

\subsection{Definition of Urban Parks}

Maulan [10] stated that urban parks are those lands that are located in urban areas and are set aside for public uses, including: recreation, aesthetic appreciation, and cultural and educational aspects. People of different ages, genders, and backgrounds use parks during all times of the day, week, and year. In any country that desires to improve the quality of life of its citizens, policy makers need to work with landscape designers and the community in order to create those green spaces where citizens and residents can enjoy fresh air and exercise; this will improve the lives of communities through improving health and providing aesthetically pleasing grounds and recreational spaces. In fact, citizens should be encouraged to participate in park planning and management with their governments.

\subsection{The Role of Urban Parks in the City}

Trees in green areas help reduce the temperature by creating shaded areas and reducing air pollution and pollutants. Chiesura [4] stated that trees help air purification through the absorption of carbon dioxide and emitting of oxygen and enhanced quality of life. In addition, the aesthetic and recreational values of public parks increase the attractiveness of any city and promote it as a tourist destination, which in turn provides economic benefits for both municipalities and citizens. Atiqul Haq [5] discussed that People who were exposed to natural environment, the level of stress decreased rapidly as compared to people who were exposed to urban environment, their stress level remained high

\subsection{Types of Urban Parks}

Ideally, urban areas contain a variety of urban park types in order to serve local leisure needs and support revitalization goals, and create or enhance an areas' sense of culture, liveliness, and identity. It is also important to pursue creative solutions to providing open space and recreation facilities in these areas. In addition, urban park types range from the very small situated as a byway on a pedestrian oriented travel way to a large civic open spaces that encompass many acres and diverse amenities and accommodates large community gatherings. Urban parks can be divided into the following types:

\section{- Mini parks}

A mini-park is designed in a neighborhood with a minimum area less than four thousand square (4000 sq.m ) meters and its purpose is to provide recreational opportunities for children.

\section{- Neighborhood parks}

The neighborhood park is designed to serve the recreational needs of children from six to fifteen (6-15) years of age as well as adults; it has an optimum area of (20,000 sq.m) meters.

\section{- Community parks}

These parks are used by youths and adults to serve a wide variety of needs, including both active and passive recreation and facilities for sports fields, playgrounds, picnic areas, and off-street parking. The area of the park is usually between forty thousand square meters and two hundred thousand square meters $(40,000-200,000$ sq.m). Such parks usually include restrooms and related facilities that comprise an area of ten thousand (10,000 sq.m). 


\subsection{Attributes Associated With Park Use}

Several features of parks influence park use and those include access to a variety of facilities within parks that support recreational activities including structured (e.g., sports) and unstructured (e.g., play) ones as shown in figure 2. McCormack et, al. [11] found that park amenities were important for park use, and those included: barbeques, seating, water fountains, picnic tables, and bathrooms; those were important regardless of age. Other specific attributes that encourage park use are the presence of shade and appropriate placement of shade-providing devices. He also added about issues that discouraged park use such: as lack of maintenance, lack of cleanliness within parks, and uneven ground or playing surfaces, lack of grass, and poor quality sidewalks. Other reasons that discouraged frequenting urban parks had to do with accessibility and park proximity; having more local parks within walking distance was positively associated with park use, while the necessity of driving to reach a park often deterred use. Encouraging factors for urban park visits included aesthetic aspects and the presence of trees and bushes, gardens, grass, flowers, natural settings, and water features. Good air quality and the presence of distinctive soothing smells of nature in parks were considered as positive attributes. McCormack et, al. [11] added, the presence of smog or fumes did not invite the use of parks. Moreover, the presence of the sounds of nature and the quietness and peace of parks made them attractive to some individuals. Another factor which presents a serious impediment to the use of urban parks is the presence of undesirable users within the parks such as drug users, or homeless persons. As such, increasing safety in parks can be maintained by the presence of good lighting, the presence of law-enforcement, and increased security surveillance. McCormack et, al. [11] concluded that the social environment appears to influence park use like organizing festivals and celebrations in parks since that brings people together from divergent backgrounds.
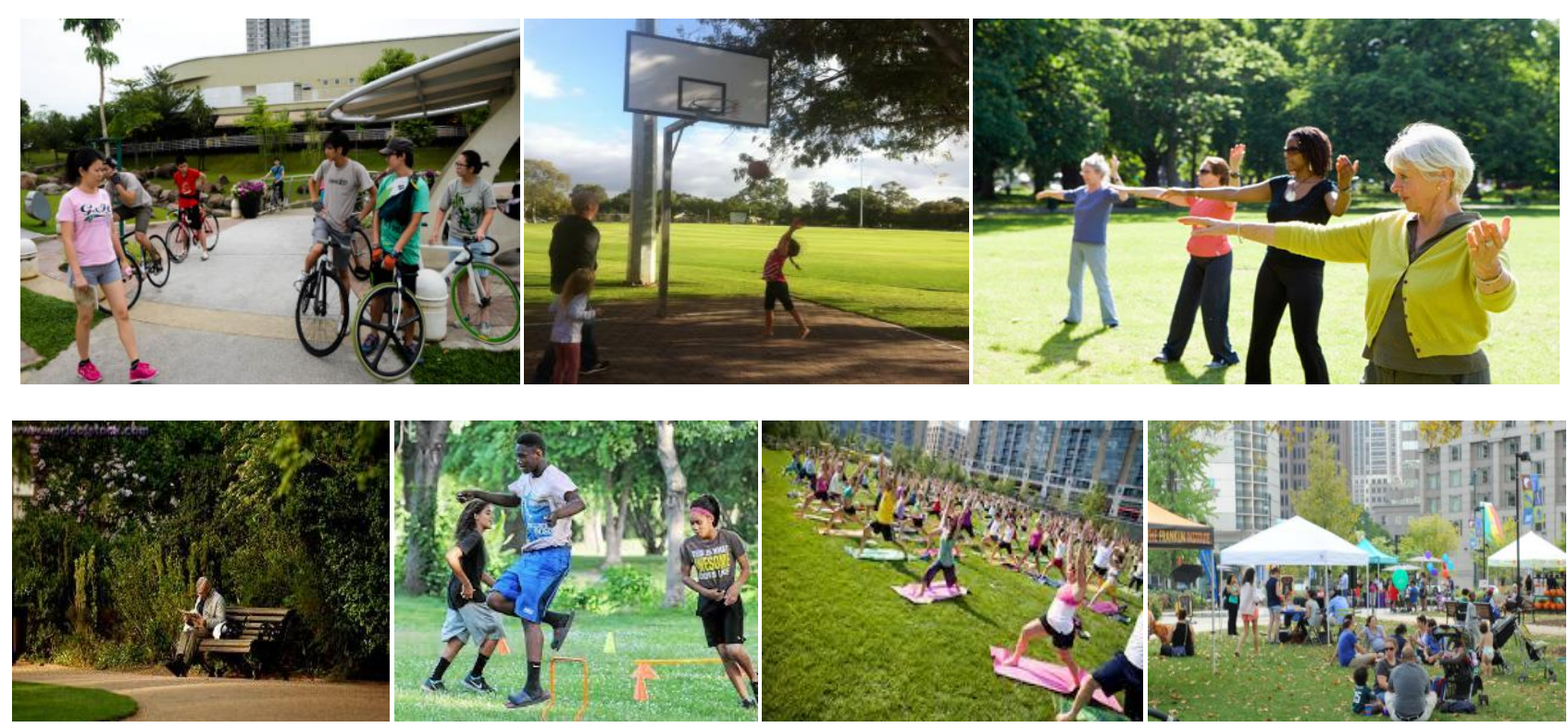

Figure 2: Different types of activities can take place in Parks

\section{PARKS AND THEIR RELATION TO LAND}

\section{USE IN BAHRAIN}

The Kingdom of Bahrain is a group of islands located off the central southern shores of the Arabian Gulf $\left(26^{\circ} 00^{\prime} \mathrm{N}\right.$, $\left.50^{\circ} 33^{\prime} \mathrm{E}\right)$. Manama, the capital of Bahrain, is where most of the commercial, governmental, and other services are located. Muharraq, the second largest island, lies northeast of the main island. The third inhabited island is Sitra, east of Bahrain. Bahraini society is considered an urban and settled society. A study of land use in different areas of Bahrain as shown in figure 3 shows that the newly developed areas like Juffair, Seef, Hamaleh, and other new developed area need less green spaces and parks because plot areas are huge, the population density is less, and some building has its own garden compared to the highly dense and old areas such as
Manama City, Muharraq Governorate and Sitra with a high population density and less natural areas with small plots 5 as shown in figure 4. Beiranvand et al. [12] delineate the minimum standard of green space to be between ten (10) to fifteen (15) square meters per person according to each country's climate as shown in table 1.

Table 1: Standards of green spaces (Rao, et al., 2013)

\begin{tabular}{|l|l|}
\hline \multicolumn{1}{|c|}{ Name of Norms } & \multicolumn{1}{c|}{ Standards } \\
\hline WHO Norms & 9 sq.m per person (www.who.org.in) \\
\hline UDPFI Guideline & $\begin{array}{l}10 \text { sq.m. - 12 sq.m. per person (For medium } \\
\text { towns and Metro cities respectively) }\end{array}$ \\
\hline
\end{tabular}

${ }^{5}$ Please see upcoming maps of different areas in Bahrain ( http://websrv.municipality.gov.bh/ppd/indexar.jsp) 


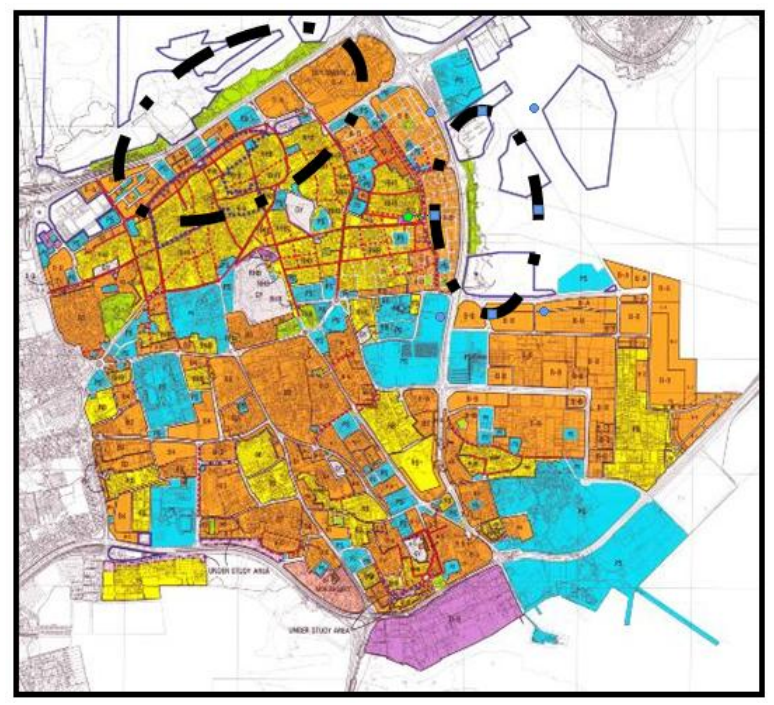

Manama City

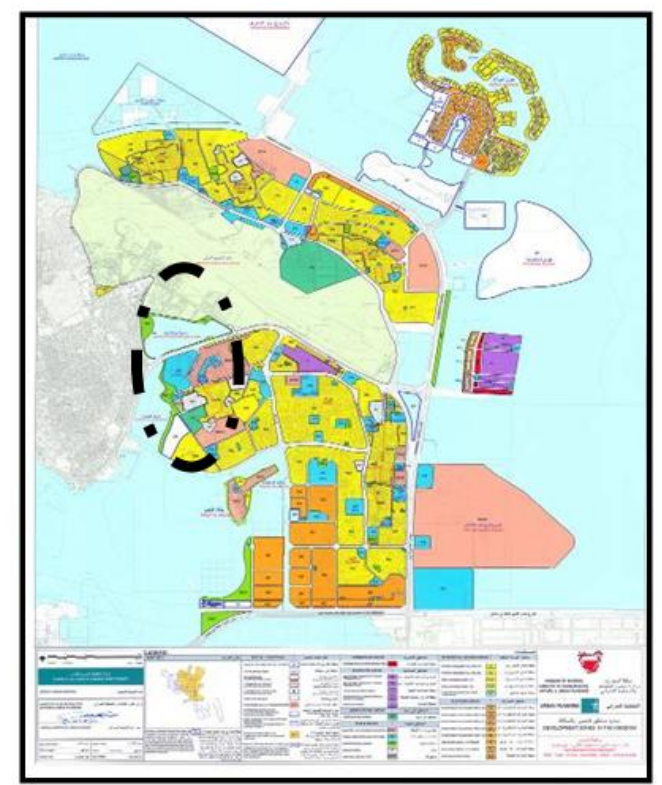

Muharraq Governorate

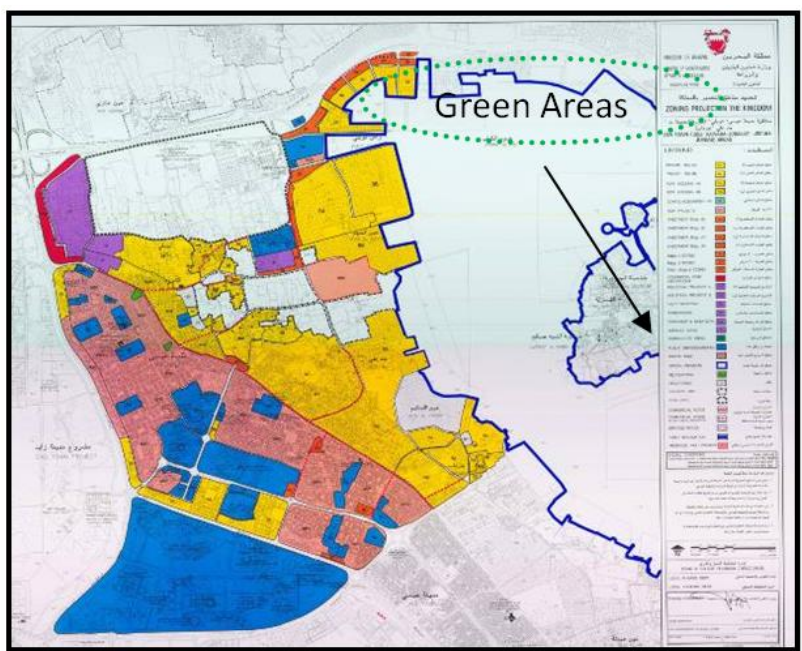

Isa Town and Tubli,

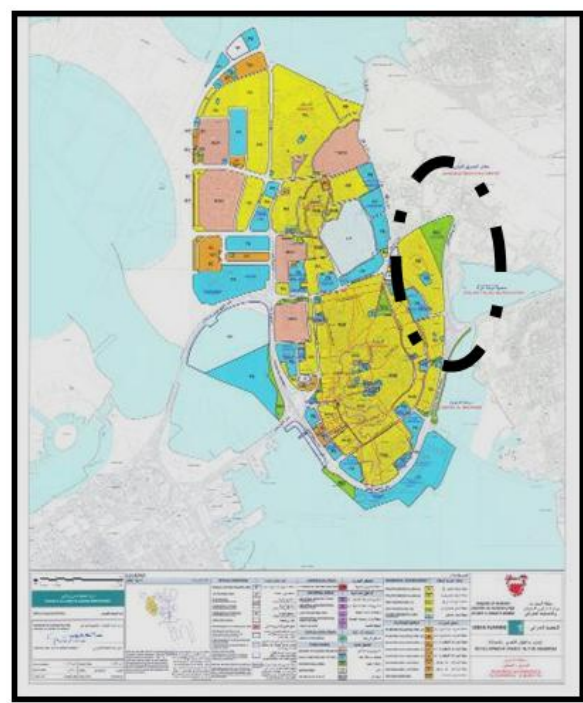

Muharraq and Busaiteen

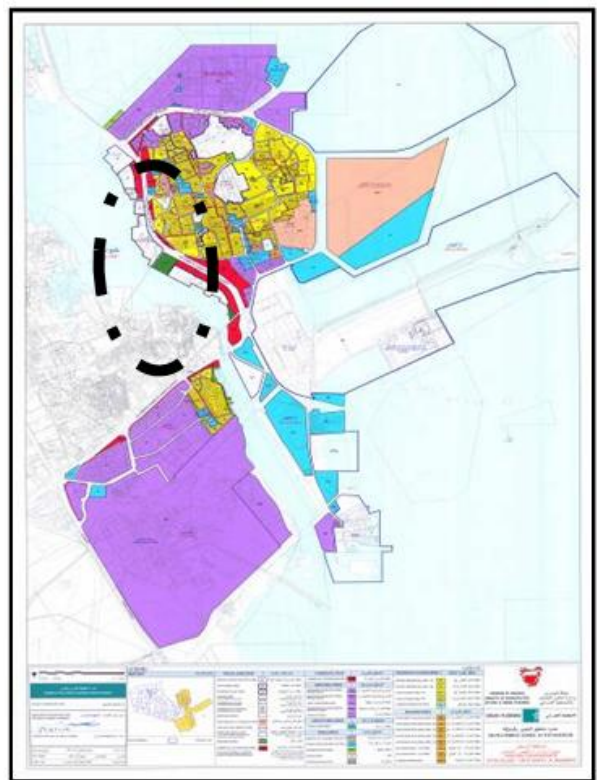

Sitra Island

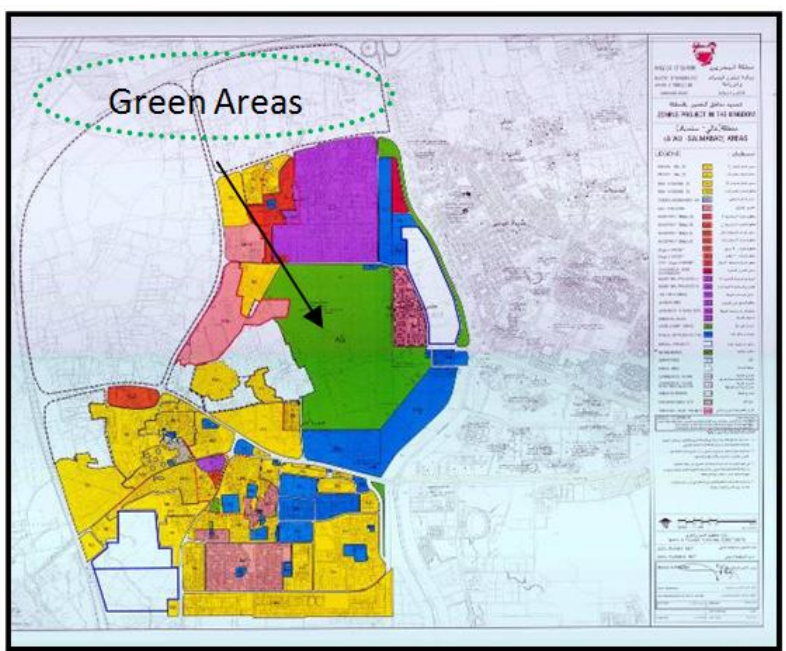

A'Ali \& Salmabad

Figure 3: Parks and its relationship with Land Use in different areas in Bahrain. 
Due to the large increase in population which estimated 650,604 person in 2001 reaching in the last population censuses in 2014 to $1,314,562$ person $^{6}$. According to AlNabi [13] the land area of Bahrain increased due to Land Reclamation mechanism from $757.9 \mathrm{~km} 2$ in 2009 to 765.3 $\mathrm{km} 2$ in 2015 .

The following data is collected from Bahrain Open Data Portal $^{7}$

The area of green parks in Manama $=344.8$ acres

Total population in Manama $=497,000$ person

Therefore, the person share of park $=344.8 / 497,000=2.77$ sq.m which is less than the standards.

The study of land use maps of Bahrain shows that the number and distribution of parks in Bahrain are not enough in relation to its population. The park space per capita in Bahrain is 2.77 sq.m while the international standard according to WHO is 9 sq.m.

6

http://www.data.gov.bh/ar/ResourceCenter/DownloadFile?i $\underline{\mathrm{d}=1453}$

${ }^{7}$ http://www.data.gov.bh/en/ResourceCenter

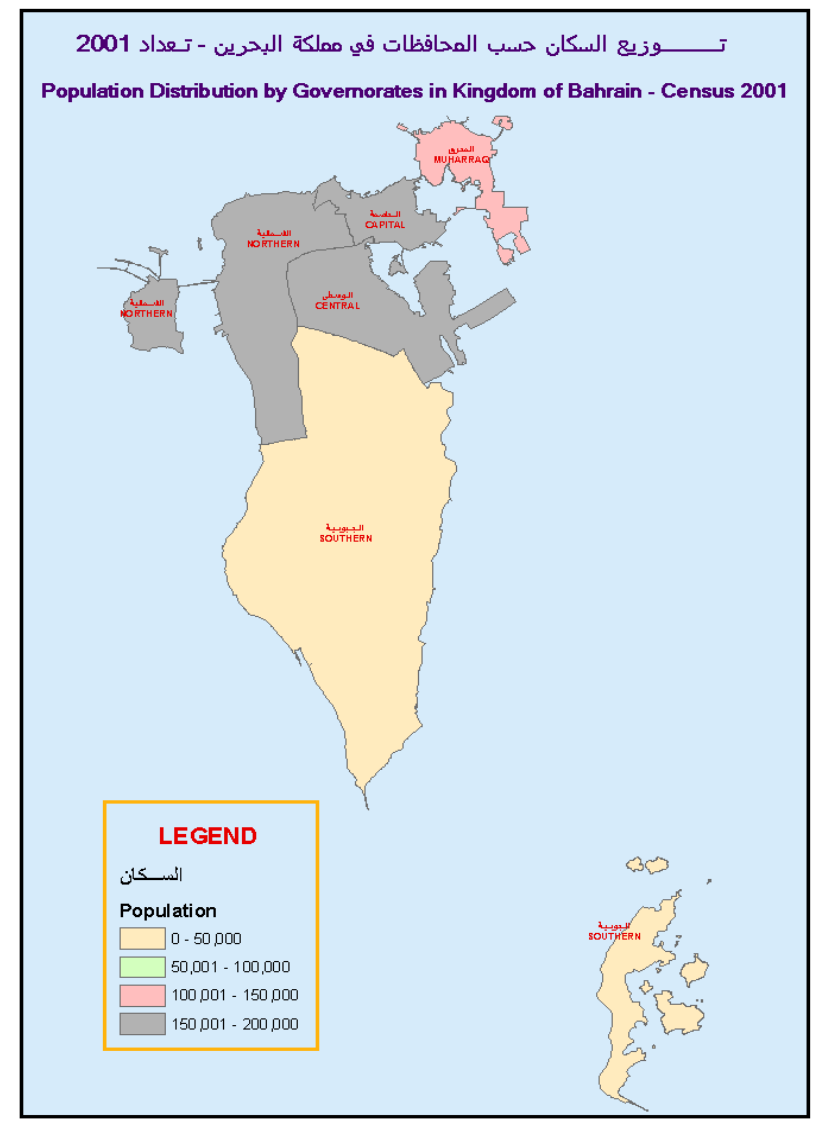

Figure 4: Population Distribution ${ }^{8}$
8 Central Informatics Organization in Bahrain:

http://www.data.gov.bh/ar/ResourceCenter/DownloadFile?i $\mathrm{d}=1307$

\subsection{Research Area \& Data Collection}

Al Andalus Park, Arad Bay/Dohat Arad and Al Fateh Conniche were selected due to their emergence as one of the best projects in Bahrain through its well planned designed ( See figure 1). The following step is to investigate the existing conditions of these parks in order to be able to extract the existing facts and potentials of them. Therefore after site analysis is to put planning and design recommendations which will become a guidelines for parks improvement in the kingdom of Bahrain.

\subsection{Findings From The Sites Visit:}

- Climate: Bahrain has two seasons: hot summer and mild winter. The summer months, from April to October, afternoon temperatures average $40^{\circ} \mathrm{C}$ and can reach $48^{\circ} \mathrm{C}$ during June and July. Humidity ranges from $33 \%$ (comfortable) to $89 \%$ (very humid) over the course of the year ${ }^{9}$. The combination of intense heat and high humidity makes this season uncomfortable. In addition, a hot, dry southwest wind periodically blows sand clouds across the barren southern end of Bahrain toward Manama in the summer. Temperatures moderate in the winter months, from November to March, when the range is between $10^{\circ} \mathrm{C}$ and $20^{\circ} \mathrm{C}$ as shown in figure 5 .

- These parks are bounded by major roads which make them affected by noise and pollution caused by vehicles.

- No activities found in all of these parks and generally they are abandoned.

- There are many facilities and elements provided in these parks such as gazebos, pergolas, walkways, dustbins, benches, ponds and railings but unfortunately these elements not reaching visitors demands.

- There is no diversity or opportunity for different types of users in these parks, only a green area and scattered trees with no overall vision. 


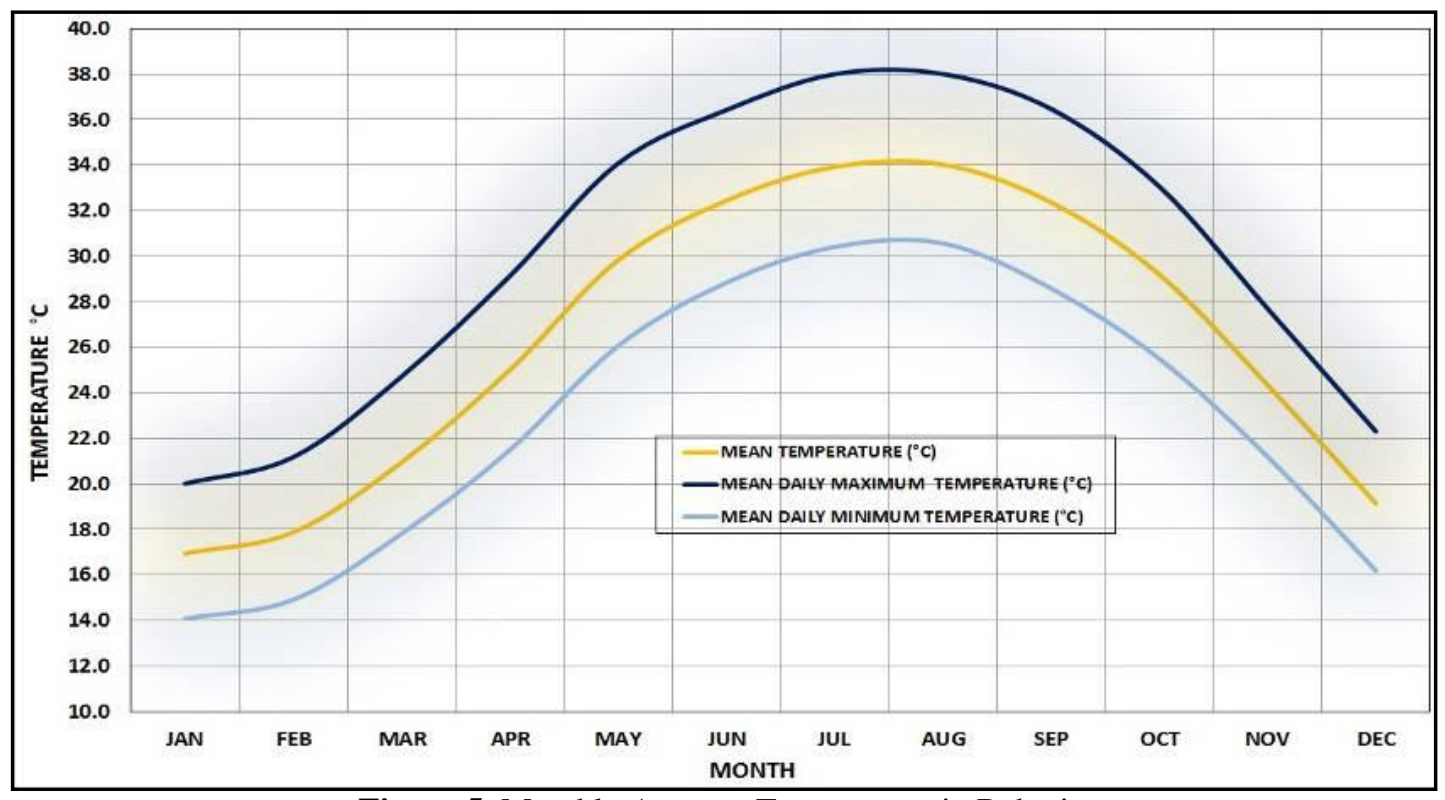

Figure 5: Monthly Average Temperature in Bahrain

\section{$\underline{1 \mathrm{db} 126058934 ? \mathrm{t}=1408264354000}$}

\subsection{Question For The Visitors}

From regular visits to these selected parks, the time periods for the data collection were October 2015. The fall season was chosen as the weather is best during this month which moreover most likely would increase the number of visitors in these parks. Questionnaires were handed out at both time periods to people using the area for a longer or shorter stay, which means that people who were just walking past the area were not included. Data were collected in the mornings, midday, evenings and in weekends in order to reach as many different users as possible. The questions included in this study concerned reasons for use. In addition, questions regarding demographic background (age, gender, education, nationality) were also posed.

Your age kind of job

$\operatorname{sex} \mathrm{M}(\quad) \mathrm{F}(\quad)$

Bahraini citizen ( ) or other ( )

\section{Questionnaire about the frequency of visits}

Q 1. How many times do you visit this park during one week?
( ) once
( ) twice
( ) 3 times
( ) 4 times
( ) 5 times
( ) other show

Q 2. On what day do you prefer to visit parks?

$\begin{array}{ll}(\quad) \text { Sat. } & (\quad) \text { Tue. } \quad(\quad) \text { Fri. } \\ (\quad) \text { Sun. } & (\quad) \text { Wed. } \\ (\quad) \text { Mon. } & (\quad) \text { Thur. }\end{array}$

Q 3. With whom do you prefer to visit parks?

( ) with your family (wife/husband, wife/husband \& children)

( ) with your friend (s)

( ) with others, who ?

Q 4. Do you use a car when you come to parks?

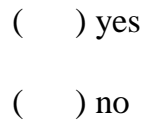

Q 5. where do you park your car?

( ) outside the park

( ) inside the park

( ) in another place

Q 6. What would encourage you a lot to visit a Park? (you can 
choose more than one answer)

( ) Improved safety

( ) Better facilities

( ) More events

( ) Easier to get to

( ) More varied vegetation ( ) Other, specify-

Q.7. Are there enough seating areas in the park?
( ) yes
( ) no
( ) don't know
( ) others

Q.8. Do you feel safe walking around the park?
( ) yes
( ) no
( ) don't know
( ) others

Q.9. How do you feel about the information signs in the park?
( ) Very satisfied
( ) satisfied
( ) not enough
( ) don't know

Q 10. What is your point of view of this park in terms of facilities such as comfort stations, snack pavilion, picnic shelters, play pavilion and parking?
( ) successful
( ) acceptable
( ) unacceptable and need repair.

Q11. What improvement would like to see in the future?
( ) playgrounds
( ) picnic grounds.
( ) exhibition space
( ) open flat land for show
( ) adult games
( ) children's playground
( ) sports activities
( ) restaurants

( ) transportation scouts

( ) preparing competition entertainment programs.

( ) others,

Q 12. Do you prefer some kinds of women's activities or special programs for elderly people and handicapped in the park?

$$
\begin{aligned}
& \text { ( ) yes } \\
& \text { ( ) no }
\end{aligned}
$$

if the answer is (yes), which kind of activities do you suggest:

Q 13. Do you have any suggestions or needs or even some thoughts you believe will serve to develop the park's condition?

Q 14. Do you want outdoor staying spaces to have facilities that can provide shade, regardless of the season? For example, trees or gazebos.

Q 15. Do you prefer outdoor staying spaces to have ponds, pools, or streams? Please explain your answer.

Q.16. Is there any unused area in the park, or has negative activities?

( ) Yes (mention where)

( ) How it can be reused? 


\section{( ) no \\ ( ) don't no}

Q 17. Our questions are nearly finished. Do you have anything else to add? Have I overlooked anything? Thank you for your valuable opinions.

\subsection{Results}

The objectives of parks survey in Bahrain were:

1. To provide baseline information regarding factors that influence whether people do or do not use the space.

2. To explore the nature and scope of people's needs and preferred activities, related to the use of the space.

3. To explore the desired types of physical activity from the people living around the space.

From the initial readings of the questionnaire results, some results can be addressed:

- The best time to visit the park according to most of people's answers was afternoon.

- Non local users were the most willing to share in park development and redesign, generally more than $55 \%$ shows the willingness and proposed some ways to be a part of the park redesign.

- Both local and non local users agreed that there are not enough shelters in the park, especially among who come in the mornings.

- Most of the age group (20-30) chooses that developing sport areas will attract them more to visit the park, while non local users choose more information signs, and last for people who come at night choose restaurant.

- Only $19 \%$ of all parks attendance like exercise while the majority of the age group chooses playing with kids.

- Visitors who come in the morning mainly choose walking before going to work, while those who come in the afternoon choose relaxing and family gathering.

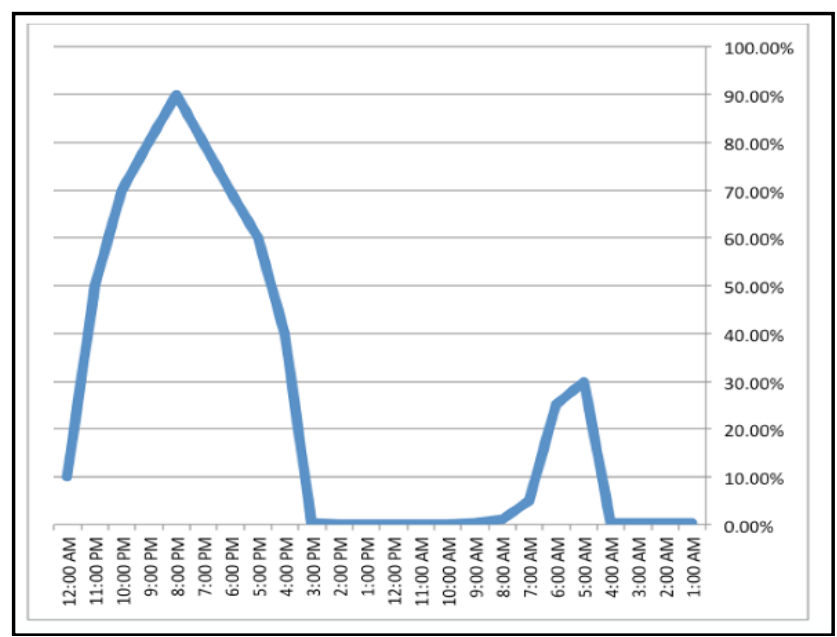

\section{- Frequency to the Parks}
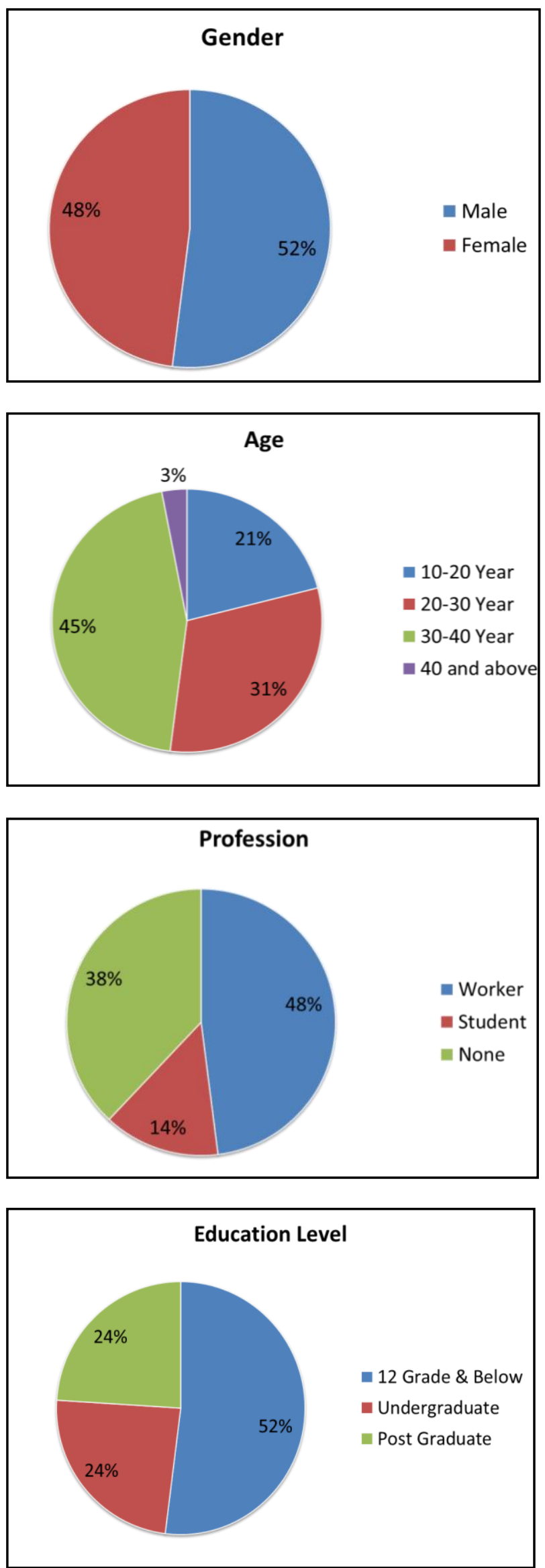

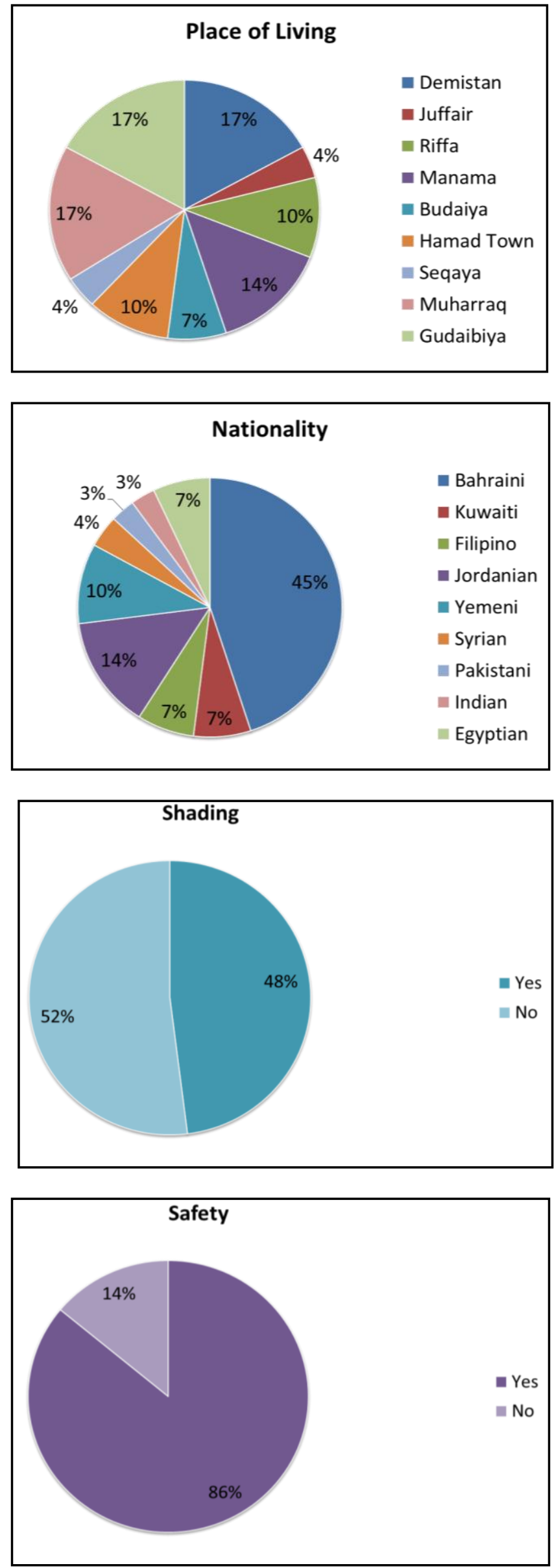
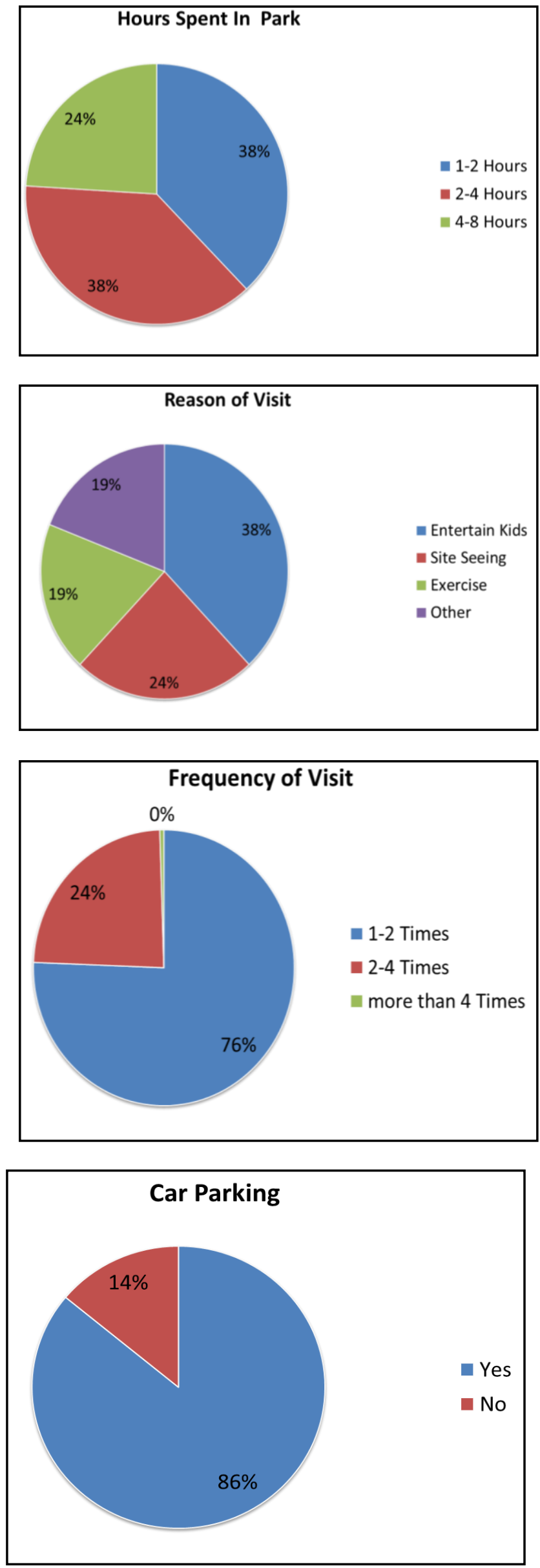


\section{DISCUSSIONS AND RECOMMENDATIONS}

Parks have a strategic importance for the quality of life in Bahrain society. The number of built-up areas is growing and increased by fast urbanization and industrialization over recent years but unfortunately parks numbers, area and facilities have little concern in relation to its population. The main objective of this study was to synthesize qualitative research findings on the use of parks. In addition to check that the number of public parks in Bahrain is enough for the people who live in Bahrain. By analyzing the questionnaire results for people visited these parks, it can be noted:

The research findings showed that climate conditions and the dearth of facilities available like playgrounds, benches, shaded seats and other seating areas were some of the reasons that the people in Bahrain in general did not visit these parks at a high rate. The survey showed that 76 per cent of people stated that they use parks one to two time a week, while the daily pattern it appears that people use these parks in the afternoons, weekends and holiday times. In addition, men are slightly higher users of parks than women, while, there is a clear indication that there is no presence for disabled people. The main reasons that people visit parks are enjoying the environment; social activities; walking activities, children amusement; sport and party activities.

As shown in the survey there is a percentage of people who did not attend parks in general, the reasons that deter people from using parks are:

- Lack of, or the poor condition of, facilities - including play for children

- Shading areas to protect them from harsh climate.

- Event activities and completions.

- No facilities for elderly and to people with disabilities.

Although some researches has found increased accessibility to parks and qualities of parks to be associated with park use and physical activity. Our review of qualitative evidence also supports the importance of accessibility for encouraging park use among children and adults regardless of gender, ethnicity, and socioeconomic status. On the other hand, qualitative evidence from our review suggests that poor conditions (e.g., uneven playing surfaces, courts with cracks, poor quality footpaths, insufficient lighting, etc.) might deter park use, therefore people would travel to visit other parks because of the attributes they offered. According to Shukur et al. [14] the best design of park had a positive impact on people's perceptions and consists of a good arrangement of park elements, variations of features and facilities, appearance, connections and have a safe and protection to meet the needs and people's interests. It is also found that features of parks that facilitated both structured (i.e., sports fields, courts) and unstructured (i.e., paths, trails) physical activity were important for encouraging park visits, and recent quantitative research by Roberto et, al. [15] suggested that parks with walking paths and trails were visited more often than parks containing sports-related facilities. On the other hand, analyzing different maps of Bahrain as shown in figure 3 , show that the number and distribution of parks are not enough and need to provide more open space to reach the standards, in addition to improving the quality of the existing parks to attract more people. The state of knowledge is now such that park and recreation services must be planned and funded based on the known physical activity health benefits they provide. The evaluation of parks in Bahrain have focus on the quality of these parks and people satisfaction. Therefore, during the planning and management process of parks a consideration of users' perception should be considered. If the development strategies for these parks fail to include stakeholders' participation, it will then neglect of people values and pattern of life.

\section{CONCLUSION}

The greatness of any city is its ability to provide recreation, natural beauty, and signature open spaces for its citizens. Successful parks pay dividends for cities in building civic pride increasing tourism, economic investment and contributing to health and quality of life. In addition theses parks should be accessible to everyone regardless of residence, physical abilities or financial resources.

From the research findings, it can be summarized that a park has many benefits and plays multiple roles no matter where it is located, whether in residential areas, commercial areas, urban areas etc. Many professionals, recognize that design often lies at the heart of what makes a successful parks. Design is also a key part of tackling many of the barriers to use of parks. Approaches to design have to vary to suit individual circumstances - from facilitating community design at one level, to high-level innovative approaches to creating new parks at the other. Quality in design must always be the aim and designers need to find the right balance for each particular situation. Community involvement of some form is now a part of mainstream activity in most places. Some of the most successful approaches seem to occur where there has been a real change in culture in the local authority parks service so that the emphasis on community involvement is core rather than partial or token.

\section{REFERENCES}

[1] Carlson, S., Fulton, J., Pratt, M., Yang, Z., Adams, E., "Inadequate Physical Activity and Health Care Expenditures in the United States", http://www.cdc.gov/nccdphp/dnpao/docs/carlson-physicalactivity-and-healthcare-expenditures-final-508tagged.pdf, 2015

[2] Fratini, R., Marone, E, "Green-space in Urban Areas: Evaluation of Efficiency of Public Spending for Management of Green Urban Areas", International Journal of E-Business Development (IJED), 2011, p:1.

[3] Abkar, M., Kamal, M., Mariapan, M., Maulan, S., Sheybanic, M., "The role of urban green spaces in mood change", Australian Journal of Basic and Applied Sciences, 4(10): 5352-5361, INSInet Publication, 2010.

[4] Chiesura, A., "The role of urban parks for the sustainable city", Landscape and Urban Planning 68 (2004) 129-138, 2004. http://isfahan.ir/Dorsapax/userfiles/file/urbanlatin.pdf 
[5] Atiqul Haq, S., "Urban Green Spaces and an Integrative Approach to Sustainable Environment". Journal of Environmental Protection, 2011, 2, 601-608.

[6] Hanie, O., Aryan, A., Mohammad Reza, L., Elham, L.," Understanding the importance of sustainable buildings in occupants' environmental health and comfort". Journal of Sustainable Development, Vol.3, No.2, June, 2010

[7] Sullivan, W.C., Kuo, F., E., DePooter, S., F., "The Fruit of Urban Nature: Vital Neighborhood Spaces. Environment and Behavior", 36,5:678-700, 2004, http://www.willsull.net/resources/Sullivan-

papers/SullivanKuoDePooter.pdf

[8] Musaiger, A., Al-Mannai,M., "Factors Related to Weight Status of the Adult Bahraini Population, Bahrain Medical Bulletin", Vol. 22, No. 3, September 2000, Available online at

http://www.bahrainmedicalbulletin.com/september_2000/we ight_status.pdf

[9] Nassar, U., "Landscape as a tool to enhance behavioral response and activities in historic urban parks", Unpublished doctoral dissertation. Suez Canal University, Egypt, 2000, p:16

[10] Maulan, S., "Seremban urban park, Malaysia", Unpublished Master's dissertation in Landscape Architecture. College of Architecture and Urban Studies, Virginia Polytechnic Institute \& State University,2002 http://scholar.lib.vt.edu/theses/available/etd-05222002-

123423/unrestricted/02chapters.pdf

[11] McCormack, G., Rock, M., Toohey, A., Hignell, D. ," Characteristics of urban parks associated with park use and physical activity", 2010, http://www.med.upenn.edu/beat/docs/McCormack2010Healt hPlaceparkuseandPA.pdf

[12] Beiranvand, A., Bonyad, A., Sousani, J., "Evaluation of Changes in Per Capita Green Space through Remote Sensing Data", International journal of Advanced Biological and Biomedical Research ISSN: 2322 - 4827, Volume 1, Issue 4, 2013: 321-330 Available online at http://www.ijabbr.com,2013, p:327

[13] AL- Nabi, M., "The History of Land use and Development in Bahrain", Information Affairs Authority, Directorate of Government Printing Press,2012 Available online:

www.housing.gov.bh/en/.../6681\%20book\%20resized.pdf

[14] Shukur, F. Othman, N., Nawawi, A., "The values of parks to the house residents". 1st National Conference on Environment-Behaviour Studies, Faculty of Architecture, Planning \& Surveying, Universiti Teknologi MARA, Shah Alam, Selangor, Malaysia, 2009.

[15] Roberto F., Enrico M., "Green-space in urban Areas: Evaluation of efficiency of public spending for management of green urban areas", International Journal of E-Business Development (IJED), 2011.

\section{BIOGRAPHIES}

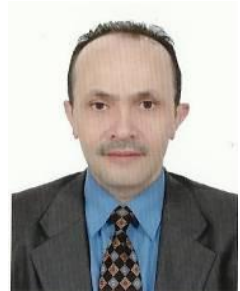

Dr. Assali received Ph.D in Architecture from Technical University of Graz (TUGRAZ) /Austia in 2001. He is from 2006- till now chairperson of Interior Design Department at Ahlia University in the Kingdom of Bahrain. 